\title{
Clinical Vignettes
}

\section{Hypercalcemia in Pregnancy: A Case of Milk-Alkali Syndrome}

\author{
Leanne Kolnick, MD' , Bryan D. Harris, MD' , David P. Choma, MD, PhD'2, and Neesha N. Choma, \\ $\mathrm{MD}, \mathrm{MPH}$
}

'Department of Medicine, Vanderbilt University Medical Center, Nashville, TN, USA; ${ }^{2}$ Department of Medicine, Division of Nephrology, Vanderbilt University Medical Center, Nashville, TN, USA.

Milk-alkali syndrome is a rare cause of hypercalcemia characterized by the triad of hypercalcemia, renal insufficiency, and metabolic alkalosis that results from the overconsumption of calcium containing products. In the setting of pregnancy where there is a physiologic increase in calcium absorption, milkalkali syndrome can be potentially life threatening. We report a case of a 26-year-old woman in her second trimester of pregnancy who presented with 2 weeks of flank pain, nausea, vomiting, anorexia, headache, and lightheadedness. The history revealed consumption of a large quantity of milk, calcium carbonate antacid, and calcium-containing prenatal vitamins. Her symptoms and hypercalcemia resolved with intravenous fluids and a loop diuretic. With the increased use of calcium carbonate for peptic ulcer disease, gastroesophageal reflux disease, and osteoporosis, milk-alkali syndrome has experienced a resurgence and must be considered in the differential diagnosis of hypercalcemia. In this clinical vignette we review the literature on milk-alkali syndrome in pregnancy and discuss important diagnostic and therapeutic considerations when managing the pregnant patient with hypercalcemia.

KEY WORDS: hypercalcemia; milk-alkali syndrome; pregnancy.

$\mathrm{J}$ Gen Intern Med 26(8):939-42

DOI: $10.1007 / \mathrm{s} 11606-011-1658-0$

(c) Society of General Internal Medicine 2011

\section{BACKGROUND}

Milk-alkali syndrome consists of the triad of hypercalcemia, renal insufficiency, and metabolic alkalosis that result from the overconsumption of calcium-containing products. It is a rare cause of hypercalcemia that is potentially life threatening. ${ }^{1}$ Sustained hypercalcemia in a pregnant patient imposes risk not only to the mother, but also to the fetus, and can result in intrauterine growth restriction and fetal demise. Milkalkali syndrome is experiencing a resurgence, and eight cases have been reported during pregnancy (Table 1). We report a case of milk-alkali syndrome in the second trimester of pregnancy.

Received May 20, 2010

Revised August 30, 2010

Accepted February 4, 2011

Published online February 24, 2011

\section{CASE REPORT}

A 26-year-old Caucasian woman (G1; T0; P0; L0) with an intrauterine pregnancy at $255 / 7$ weeks presented with 2 weeks of nausea, vomiting, anorexia, left-sided flank pain, headaches, and lightheadedness. She had a history of gastroesophageal reflux disease with worsening symptoms throughout pregnancy and reported taking 8-9 tablets of regular or extra-strength over-the-counter calcium carbonate antacid daily; each tablet contained $200 \mathrm{mg}$ or $400 \mathrm{mg}$ of elemental calcium, respectively. Additionally, she consumed several glasses of milk and a calcium-containing prenatal vitamin daily. Her intake of elemental calcium ranged between 2,500$4,400 \mathrm{mg}$ daily. She had no medical history of pancreatitis, cholelithiasis, cholecystitis, renal disease, hypertension, nephrolithiasis, fractures, or malignancy. She did not have a family history of parathyroid disease or hypercalcemia. She denied use of non-steroidal anti-inflammatory medications, diuretics, or herbal medications, and she had no exposure to intravenous contrast media. She denied alcohol or illicit drug use, but was smoking 1-2 cigarettes daily, with a 7-pack-year history.

Upon admission, examination revealed a lethargic woman, oriented to person, place, and time. Her temperature was 98.3 ${ }^{\circ} \mathrm{F}$, blood pressure 140/84 $\mathrm{mmHg}$, pulse 83 beats per minute, and respiratory rate 20 breaths per minute. Her physical exam was notable for dry mucous membranes, decreased breath sounds at the lung bases, soft abdomen with palpable gravid uterus, normal bowel sounds, and bilateral flank tenderness. Jugular veins were flat, and there was trace bilateral lower extremity edema. Fetal heart rate was 135 beats per minute.

Laboratory values were significant for total calcium of $17.7 \mathrm{mg} / \mathrm{dl}$ (normal 8.4-10.2), ionized calcium $9.2 \mathrm{mg} / \mathrm{dl}$ (normal 4.5-5.3), and albumin $3.4 \mathrm{gm} / \mathrm{dl}$ (normal 3.5-5.0). Creatinine was $1.9 \mathrm{mg} / \mathrm{dl}$ (normal 0.75-1.50), urea nitrogen $23 \mathrm{mg} / \mathrm{dl}$ (normal 5-25), and bicarbonate $30 \mathrm{mEq} / 1$ (normal 22-28). Based on a urinalysis that showed a specific gravity of 1.010, pH 5.5, and significant white blood cells and leukocyte esterase, she received ampicillin and ceftriaxone. Additional laboratory work revealed normal serum lipase, amylase, alkaline phosphatase, liver transaminases, vitamin A, vitamin D 25-OH, and thyroid function. Fractional excretion of sodium was $2.5 \%$. Intact parathyroid hormone (iPTH) level, parathyroid-related peptide (PTH-rp) level, vitamin D 1,25-OH, phosphorous, potassium, and magnesium levels were low (Tables 2 and 3). An arterial blood gas analysis showed alkalemia with a $\mathrm{pH}$ of 7.47 (Table 2), and iron studies were consistent with iron deficiency of pregnancy. A renal ultrasound showed enlarged kidneys with echogenic medullae, consistent with medullary nephrolithiasis. 
Table 1. Comparison of Reported Cases of Milk-Alkali Syndrome in Pregnancy

\begin{tabular}{|c|c|c|c|c|c|c|}
\hline $\begin{array}{l}\text { Case } \\
\text { report }^{(\text {Ref })}\end{array}$ & Age & $\begin{array}{l}\text { Weeks } \\
\text { gestation }\end{array}$ & $\begin{array}{l}\text { Peak calcium } \\
\text { (mg/dl) }\end{array}$ & $\begin{array}{l}\text { Presenting } \\
\text { creatinine }(\mathrm{mg} / \mathrm{dl})\end{array}$ & $\begin{array}{l}\text { Recovery of } \\
\text { Creatinine }\end{array}$ & Outcome of pregnancy \\
\hline $1\left(^{19}\right)$ & 35 & 35 & 16.5 & 2.2 & Yes & $\begin{array}{l}\text { Baby recovered from hypercalcemia, } \\
\text { jaundice and sepsis }\end{array}$ \\
\hline $2\left({ }^{21}\right)$ & 40 & 38 & 18.2 & 1.9 & Yes & Uncomplicated \\
\hline $3\left({ }^{20}\right)$ & 31 & 23 & 14.3 & 2.1 & & $\begin{array}{l}\text { Stillborn at } 37 \text { weeks (short limbs, } \\
\text { low set ears, normal chromosome } \\
\text { analysis) }\end{array}$ \\
\hline $4\left({ }^{14}\right)$ & 32 & 16 & 22.0 & 1.4 & Yes & Not reported \\
\hline $5\left(^{28}\right)$ & Not reported & 35 & 16.2 & 1.4 & Yes & Uncomplicated \\
\hline $6\left(^{29}\right)$ & 31 & 36 & 22.5 & 1.9 & Yes & Uncomplicated \\
\hline $7\left({ }^{30}\right)$ & 38 & 37 & $16.0^{*}$ & 5.2 & Yes & Uncomplicated \\
\hline $8\left({ }^{31}\right)$ & 32 & 39 & 15.5 & 1.4 & Yes & Uncomplicated \\
\hline Our Case & 26 & 25 & 17.7 & 2.1 & Yes & Uncomplicated \\
\hline
\end{tabular}

*Only corrected calcium reported

The patient was aggressively volume resuscitated with 41 of normal saline and was given one dose of $40 \mathrm{mg}$ intravenous furosemide. She produced more than 41 of urine the first night of admission and did not require additional furosemide. She continued on maintenance intravenous fluids until able to maintain adequate oral intake. Her hypokalemia, hypophosphatemia, and hypomagnesemia were treated with supplements.

On discharge, hospital day 4 , her calcium was $8.2 \mathrm{mg} / \mathrm{dl}$, ionized calcium $4.69 \mathrm{mg} / \mathrm{dl}$, and phosphorous $2.0 \mathrm{mg} / \mathrm{dl}$. Serum bicarbonate and creatinine improved to $20 \mathrm{mmol} / \mathrm{l}$ and $1.3 \mathrm{mg} / \mathrm{dl}$, respectively. She was discharged with oral magnesium oxide and K-Phos Neutral. She was prescribed a proton pump inhibitor for her reflux and advised not to use over-thecounter calcium-containing antacids. Her prenatal vitamin was restarted. Three days after discharge, her calcium level remained within normal limits.

\section{DISCUSSION}

In Chicago in 1915, Dr. Bertram Sippy, based on the Schwartz dictum "no acid, no ulcer," developed a treatment for peptic ulcer disease that consisted of frequent consumption of milk and cream with eggs and cereal added later. ${ }^{2}$ His regimen also recommended frequent administration of alkaline powders (calcium carbonate, sodium bicarbonate, magnesium oxide, and bismuth subcarbonate) given in between feedings. ${ }^{3}$ In 1926 , Hardt and Rivers published a report of 16 patients using the Sippy regimen who developed headache, nausea, vomiting, irritability, and weakness. ${ }^{4}$ In 1936 Cope reported that treatment of peptic ulcer disease was associated with hypercalcemia, renal failure, and alkalosis, establishing the milk-alkali syndrome. ${ }^{1}$ After the advent of nonabsorbable antacids, histamine-2 blockers, and proton pump inhibitors, the incidence of milk-alkali syndrome decreased significantly. ${ }^{5}$ In the 1970 s and 1980s milkalkali syndrome began to take on a different form and was seen in patients who were taking calcium carbonate and had predisposing conditions (i.e. vomiting, hypertension, hypokalemia, chronic renal insufficiency, hemorrhage, or thiazide use). Now, with the recent increased use of calcium and vitamin D supplements to treat osteoporosis, along with calcium carbonate use to treat other common conditions such as peptic ulcer disease and gastroesophageal reflux disease, milk-alkali syndrome is again on the rise. ${ }^{6}$ Due to the heightened focus on prevention and treatment of osteoporosis, women are more frequently diagnosed with milk-alkali syndrome. ${ }^{6}$ To reflect this change in etiology, some have proposed changing the name of this condition to "calcium-alkali syndrome." 7

In pregnant women, measured total serum calcium is decreased because of hypoalbuminemia but ionized calcium remains normal. ${ }^{8,9}$ Hypoalbuminemia in pregnancy is due to increases in total body water. Interpretation of serum calcium, especially in pregnancy, thus requires correction of the total

Table 2. Laboratory Investigations During the Course of Hospitalization

\begin{tabular}{|c|c|c|c|c|c|}
\hline $\begin{array}{l}\text { Laboratory tests } \\
\text { (normal range) }\end{array}$ & $\begin{array}{l}\text { Admission } \\
\text { laboratory } \\
\text { tests }\end{array}$ & Day 1 & Day 2 & Day 3 & Day 4 \\
\hline $\begin{array}{l}\text { Sodium (135- } \\
145 \mathrm{mEq} / \mathrm{l})\end{array}$ & 132 & 136 & 138 & 140 & 138 \\
\hline $\begin{array}{l}\text { Potassium (3.3- } \\
4.8 \mathrm{mEq} / \mathrm{l})\end{array}$ & 3.3 & 3.4 & 3.7 & 4.1 & 3.5 \\
\hline $\begin{array}{l}\text { Chloride (95- } \\
105 \mathrm{mEq} / \mathrm{l})\end{array}$ & 94 & 104 & 108 & 117 & 115 \\
\hline $\begin{array}{l}\text { Bicarbonate (23- } \\
30 \mathrm{mmol} / \mathrm{l})\end{array}$ & 30 & 26 & 24 & 18 & 20 \\
\hline Urea (5-25 mg/dl) & 23 & 19 & 26 & 13 & 9 \\
\hline $\begin{array}{l}\text { Creatinine }(0.7- \\
1.5 \mathrm{mg} / \mathrm{dl})\end{array}$ & 1.9 & 2.1 & 1.9 & 1.5 & 1.3 \\
\hline $\begin{array}{l}\text { Calcium (8.5- } \\
10.5 \mathrm{mg} / \mathrm{dl})\end{array}$ & 17.7 & 15.1 & 12.8 & 9.3 & 8.2 \\
\hline $\begin{array}{l}\text { Albumin }(2.6- \\
5.1 \mathrm{~g} / \mathrm{dl})\end{array}$ & 3.4 & 3.3 & & & \\
\hline $\begin{array}{l}\text { Ionized calcium } \\
(4.88-5.28 \mathrm{mg} / \mathrm{dl})\end{array}$ & 9.2 & 8.7 & 7.13 & 5.25 & 4.69 \\
\hline $\begin{array}{l}\text { Glucose }(70- \\
110 \mathrm{mg} / \mathrm{dl})\end{array}$ & 91 & 123 & 80 & 81 & 82 \\
\hline $\begin{array}{l}\text { Phosphorus (2.5- } \\
4.5 \mathrm{mg} / \mathrm{dl})\end{array}$ & & 0.5 & 1.0 & 1.0 & 2.0 \\
\hline $\begin{array}{l}\text { Magnesium (1.8- } \\
2.4 \mathrm{mg} / \mathrm{dl})\end{array}$ & & 1.0 & 1.7 & 1.4 & 1.7 \\
\hline $\begin{array}{l}\text { White blood cells } \\
(3.9-10.7 \text { thou/ul) }\end{array}$ & 17.4 & 14.6 & 13.6 & 12.0 & 14.1 \\
\hline $\begin{array}{l}\text { Packed cell volume } \\
(36-43 \%)\end{array}$ & 26.5 & $23^{*}$ & 28 & 25 & 26 \\
\hline $\begin{array}{l}\text { Platelets }(135- \\
371 \text { thou/ul) }\end{array}$ & 246 & 222 & 202 & 186 & 178 \\
\hline Arterial pH & & 7.47 & 7.44 & 7.38 & 7.32 \\
\hline $\mathrm{pCO}_{2}$ & & 38 & & & \\
\hline $\mathrm{pO}_{2}$ & & 102 & & & \\
\hline $\begin{array}{l}\text { Urate (3.6thou/ } \\
\text { ul8.3 mg/dl) }\end{array}$ & 11.7 & 10.9 & 10.0 & & \\
\hline
\end{tabular}

*Transfused 2 units of packed red blood cells after this value 
Table 3. Laboratory Investigations Performed in the Assessment of Hypercalcemia

\begin{tabular}{lll}
\hline \hline Laboratory tests & Result & Normal range \\
\hline $\begin{array}{l}\text { Intact parathyroid } \\
\text { hormone (PTH) }\end{array}$ & $5 \mathrm{pg} / \mathrm{ml}$ & $10-65 \mathrm{pg} / \mathrm{ml}$ \\
PTH-related protein & $<2.1 \mathrm{pmol} / 1$ & $0.0-4.0 \mathrm{pmol} / 1$ \\
Vitamin A & $0.68 \mathrm{mg} / 1$ & $0.3-1.2 \mathrm{ml} / 1$ \\
$1,25(\mathrm{OH})_{2}$ Vitamin D & $<8 \mathrm{pg} / \mathrm{ml}$ & $18-78 \mathrm{pg} / \mathrm{ml}$ \\
$24-\mathrm{h}$ urine protein & $0.44 \mathrm{~g}$ & $<0.15 \mathrm{~g}$ \\
Total serum protein & $5.2 \mathrm{~g} / \mathrm{dl}$ & $6.1-8.4 \mathrm{~g} / \mathrm{dl}$ \\
Free thyroxine & $0.79 \mathrm{ng} / \mathrm{dl}$ & $0.5-1.2 \mathrm{ng} / \mathrm{dl}$ \\
Thyroid stimulating & $0.81 \mathrm{mcU} / \mathrm{ml}$ & $0.3-5.0 \mathrm{mcU} / \mathrm{ml}$ \\
hormone (TSH) & & \\
\hline
\end{tabular}

calcium for albumin or direct measurement of ionized calcium. Hypercalcemia in pregnancy is most often due to primary hyperparathyroidism; however, eight cases of milk-alkali syndrome in pregnancy have been reported. ${ }^{10}$ Gastroesophageal reflux disease is a common problem in pregnancy, occurring in $30-56 \%$ of all pregnancies. ${ }^{11,12}$ Women frequently self-medicate with over-the-counter antacids. Excessive calcium alone can lead to milk-alkali syndrome, but in pregnancy this problem may be compounded by the fetus's increased need for calcium, which leads to increased absorption of calcium by the maternal gastrointestinal tract. This mechanism is mediated by 1,25dihydroxyvitamin D, placental lactogen and prolactin. ${ }^{8}$ Calcitriol, frequently increased during pregnancy, also contributes to increased uptake of calcium. ${ }^{13}$ An additional problem encountered in pregnancy and a prominent feature of pregnancy-related milk-alkali syndrome is dehydration related to vomiting. ${ }^{14}$

In our patient, the amount of elemental calcium ingested was approximately $2,500-4,400 \mathrm{mg}$, three to five times the normal daily intake. Other case reports of milk-alkali syndrome in pregnancy were associated with similar levels of calcium intake. Her normal level of 25-OH vitamin D demonstrated this was not a case of vitamin D intoxication, and the suppressed $1,25-\mathrm{OH}$ vitamin D excluded a granulomatous cause for hypercalcemia. The suppressed $1,25-\mathrm{OH}$ vitamin D was likely due to both hypercalcemia-mediated PTH suppression, as PTH activates the 1-alpha-hydroxylase activity in the proximal tubule, and renal failure itself. ${ }^{15}$ Calcium homeostasis is intimately linked with phosphorus and magnesium metabolism. This is demonstrated in our patient who had hypophosphatemia and hypomagnesemia. Her cause of her hypophosphatemia was multifactorial because of the phosphorus binding effect of the ingested elemental calcium, diminished intestinal absorption of phosphorus secondary to her decreased levels of $1,25-\mathrm{OH}$ vitamin $\mathrm{D}$, and increased fetal usage of phosphorus. ${ }^{16}$ Phosphorus is absorbed in the small intestine in co-transport with sodium in a process regulated by $1,25-\mathrm{OH}$ vitamin $\mathrm{D} .{ }^{16}$ The increased intake of calcium in milk-alkali syndrome prevents the absorption of phosphorus by the formation of an insoluble, non-absorbable salt. ${ }^{16}$ Although this calcium-phosphorus salt prevents absorption of phosphorus, excess calcium remains in the gastrointestinal tract and is capable of being absorbed. Her hypomagnesemia was due to impaired magnesium resorption secondary to the increased filtered load of calcium. ${ }^{17}$ At discharge, our patient's total and ionized calcium dropped to levels slightly below normal. This was expected because mild hypocalcemia is seen in normal pregnancies and hypocalcemia in response to treatment with saline diuresis is a feature unique to milk-alkali syndrome. ${ }^{18}$
Long-standing elevation in maternal calcium has been associated with intrauterine growth restriction, preterm delivery, fetal demise, lower birth weight, and neonatal tetany, but the effects of short-term elevations in calcium with milk-alkali syndrome are unknown. ${ }^{19}$ The workup of each reported pregnancy-related milk-alkali syndrome case, including ours, included exclusion of other common causes of hypercalcemia. Vitamin A, vitamin D, thyroid hormone, and parathyroid hormone levels were checked, and assessments were made of adrenal function and potential for malignancy. Although Sippy's classical description of laboratory values for milk-alkali syndrome included increased or normal phosphorus, our patient, like the majority of recently described cases, demonstrate a low phosphorous level. ${ }^{6}$ This difference is also reflective of the change in etiology from a cream and milk origin, high in phosphorus, to a calcium carbonate one. ${ }^{7}$ In all cases intravenous hydration has been an essential component of treatment.

Two of the reported cases of milk-alkali syndrome in pregnancy were complicated by pancreatitis ${ }^{20,21}$ and another by seizures and eclampsia. ${ }^{22}$ In the case described by Bailey where a multiparous patient presented with seizures, treatment with bisphosphonates was initiated after delivery. ${ }^{22}$ Our patient's renal dysfunction was complicated by the presence of a concurrent urinary tract infection. Treatment with ceftriaxone was avoided because the calcium-containing solution is known to cause a fatal precipitation reaction in neonates. ${ }^{23}$

Hypercalcemia causes acute kidney injury by several mechanisms, including decreasing renal blood flow by afferent arteriolar vasoconstriction, volume depletion, and tubular obstruction. ${ }^{7}$ The degree of our patient's renal failure was significant as normal pregnancy induces a state of glomerular hyperfiltration and a low serum creatinine in normal pregnancy. Her creatinine elevation to $2.1 \mathrm{mg} / \mathrm{dl}$ reflected a large decrease in glomerular filtration rate.

Classically milk-alkali syndrome is a metabolic alkalosis. Our patient's arterial blood gas revealed a mixed acid-base disorder. During normal pregnancy there is a chronic respiratory alkalosis due to an increased respiratory drive stimulated by higher circulating levels of progesterone. ${ }^{24}$ In the presence of normal renal function, this is compensated by a very mild metabolic acidosis. This patient's serum bicarbonate was elevated on admission, reflecting a profound metabolic alkalosis. The cause of her metabolic alkalosis was multifactorial, likely because of vomiting-induced hypochloremia, hypokalemia, and failure to excrete the ingested load of alkali due to acute kidney injury. Metabolic alkalosis is normally compensated for by a respiratory acidosis; her PCO2 of $38 \mathrm{mmHg}$ was caused by an inadequate respiratory compensation caused by her pre-existing respiratory alkalosis. Proper interpretation of acid-base status was imperative to management because the goal was not to return her back to a normal arterial blood gas, but instead to return her to a blood gas that accounted for the chronic respiratory alkalosis normally seen in pregnancy.

\section{CONCLUSIONS}

Our patient's ingestion of calcium carbonate, significant quantities of milk, and a prenatal vitamin containing calcium 
combined with her volume-depleted state and acid loss from vomiting led to her state of milk-alkali syndrome. Given her pregnancy and significant volume depletion, fluid resuscitation proved to be the optimal treatment. Bisphosphonates were not an option due to their contraindication in pregnancy. In addition, they should be used with caution in the setting of renal failure.

Acid reflux, due to hormonal changes, is common in pregnancy. Health care practitioners should be vigilant to ask about reflux symptoms and ensure appropriate doses of antacids are used. Previous reports indicate that $1.2-1.5 \mathrm{~g}$ of elemental calcium daily (3.0-3.75 g calcium carbonate) may be safe in non-pregnant patients; however, this threshold may need to be adjusted in pregnancy given the increased intestinal absorption. ${ }^{18}$ Two recent meta-analyses and a cohort study examined histamine 2-receptor antagonist or proton pump inhibitor use in pregnancy and found that each appear safe.$^{25-27}$ If small doses of antacids do not mitigate a pregnant patient's reflux disease, practitioners should not hesitate to transition to histamine 2receptor antagonists or proton pump inhibitors.

Our case demonstrates the potential harm of using excessive doses of over-the-counter medications containing calcium carbonate. Given the recent increase in calcium carbonate usage for treatment of osteoporosis and gastroesophageal reflux disease, milk-alkali syndrome must be considered for patients presenting with hypercalcemia.

\section{Additional Contributors: None}

Funders: None

Prior Presentations: SGIM 2010 Annual Meeting Vignette Poster Session 1.

\section{Conflict of Interest: None disclosed.}

Corresponding Author: Neesha N. Choma, MD, MPH; Department of Medicine, Vanderbilt University Medical Center, D-3100 Medical Center North, Nashville 37232, TN, USA (e-mail: neesha.choma@ vanderbilt.edu).

\section{REFERENCES}

1. Cope CL. Base changes in alkalosis produced by the treatment of gastric ulcers with alkalies. Clin Sci. 1936;2:297-300.

2. Haubrich WS. Sippy of the Sippy diet regimen. Gastroenterology. 2005; 128(4):832.

3. Sippy BW. Gastric and duodenal ulcer: medical cure by an efficient removal of gastric juice corrosion. JAMA. 1915;64:1625-30.

4. Hardt LL, Rivers AB. Toxic manifestations following the alkaline treatment of peptic ulcer. Arch Intern Med. 1923;31:171-86.

5. Jamieson MJ. Hypercalcemia. Br Med J. 1985;290:378-82.

6. Beall DP, Henslee HB, Webb HR, Scofield RH. Milk-alkali syndrome: a historical review and description of the modern version of the syndrome. Am J Med Sci. 2006;331(5):233-42.

7. Patel AM, Goldfarb S. Got Calcium? Welcome to milk-alkali syndrome. J Am Soc Nephrol. 2010; e1-4
8. Kovacs CS, Kronenberg HM. Maternal-fetal calcium and bone metabolism during pregnancy, puerperium, and lactation. Endocr Rev. 1997; 18:832-872.

9. Gagel RF. Primer on the Metabolic Bone Diseases and Disorders of Mineral Metabolism. 2nd ed. New York: Raven Press; 1993:411-512.

10. Kelly TR. Primary hyperparathyroidism during pregnancy. Surgery. 1991;110:1028-33.

11. Richter JE. Gastroesophageal reflux disease during pregnancy. Gastroenterol Clin North Am. 2003;32:235-61.

12. Fill Malfertheiner S, Malfertheiner MV, Monkemuller K, Rohl FW, Malfertheiner P, Costa SD. Gastroesophageal reflux disease and management in advanced pregnancy: a prospective survey. Digestion. 2009;79(2):115-20.

13. Ardawi MSM, Nasrat HAN, Ba'Aqueel HS. Calcium-regulating hormones and parathyroid hormone-related peptide in normal human pregnancy and postpartum: a longitudinal study. Eur J Endocrinol. 1997; 137:402-409.

14. Picolos MK, Sims CR, Mastrobattista JM, Carroll MA, Lavis VR. Milk-alkali syndrome in pregnancy. Obstet Gynecol. 2004;104(5 Pt 2):1201-4.

15. St-Arnaud R, Arabian A, Yu VW, Akhouayri O, Knutson JC, Strugnell SA. 1 alpha, 24(S)(OH)2D2 normalizes bone morphology and serum parathyroid hormone without hypercalcemia in 25-hydroxyvitamin D-1hydroxylase (CYP27B1)-deficient mice, an animal model of vitamin D deficiency with secondary hyperparathyroidism. J Endocrinol Investig. 2008; 1(8):711-7.

16. Goodman, WG, Quarles, LD. Brenner and Rector's The Kidney, 8th edition. Philadelphia: Saunders Elsevier. 2007. 1904-1930.

17. Agus ZS. Hypomagnesemia. J Am Soc Nephrol. 1999;10(7):1616-22.

18. Beall DP, Scofield RH. Milk-alkali syndrome associated with calcium carbonate consumption. Med Baltimore. 1995;74:89-96.

19. Amaya Garcia MJ, Acosta Feria M, Soto Moreno A, et al. Primary hyperparathyroidism in pregnancy. Gynecol Endocrinol. 2004;18:114-4.

20. Gordon MV, McMahon LP, Hamblin PS. Life-threatening milk-alkali syndrome resulting from antacid ingestion during pregnancy. Med $\mathrm{J}$ Aust. 2005;182(7):350-1.

21. Ullian ME, Linas SL. The milk-alkali syndrome in pregnancy. Miner Electrolyte Metabol. 1988;14(4):208-10.

22. Bailey CS, Weiner JJ, Gibby OM, Penney MD. Excessive calcium ingestion leading to milk-alkali syndrome. Ann Clin Biochem. 2008;45 (5):527-9.

23. Bradley JS, Wassel RT, Lee L, Nambiar S. Intravenous ceftriaxone and calcium in the neonate: assessing the risk for cardiopulmonary adverse events. Pediatrics. 2009;123(4):e609-13.

24. Wise RA, Polito AJ, Krishnan v. Respiratory physiologic changes in pregnancy. Immunol Allergy Clin N Am. 2006;26:1-12.

25. Gill SK, O'Brien L, Einarson TR, Koren G. The safety of proton pump inhibitors (PPIs) in pregnancy: a meta-analysis. Am J Gastroenterol. 2009; 104(6): 1541-5.

26. Gill SK, O'Brien L, Koren G. The safety of histamine 2 (H2) blockers in pregnancy: a meta-analysis. Dig Dis Sci. 2009;54(9): 1835-8.

27. Pasternak B, Hviid A. Use of proton-pump inhibitors in early pregnancy and the risk of birth defects. N Engl J Med. 2010;363:2114-23.

28. Ennen CS, Magann EF. Milk-alkali syndome presenting as acute renal insufficiency during pregnancy. Obstet Gynecol. 2006;108(3 Pt 2):785-6.

29. Kleinman GE, Rodriquez H, Good MC, Caudle MR. Hypercalcemic crisis in pregnancy associated with excessive ingestion of calcium carbonate antacid (milk-alkali syndrome): Successful treatment with hemodialysis. Obstet Gynecol. 1991;78(3 Pt 2):496-9.

30. Morton A. Milk-alkali syndrome in pregnancy, associated with elevated levels of parathyroid hormone-related protein. Intern Med $\mathrm{J}$. 2002;32:492-6.

31. Addington S, Larson N, Scofield RH. Milk-alkali syndrome in preeclamptic pregnancy: report of a patient and evaluation of albumincorrected calcium in pre-eclamptic pregnancies. J Okla State Med Assoc. 2006;99(9):480-4. 